\title{
Choosing among Competing Blockbusters: Does the Identity of the Third-Party Payer Matter for Prescribing Doctors?
}

\author{
Dag Morten Dalen \\ Enrico Sorisio \\ Steinar Strøm
}

CESIFO WORKING PAPER NO. 3227

CATEGORY 11: INDUSTRIAL ORGANISATION

OCTOBER 2010

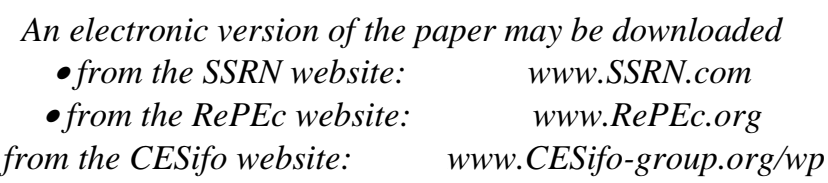




\title{
Choosing among Competing Blockbusters: Does the Identity of the Third-Party Payer Matter for Prescribing Doctors?
}

\begin{abstract}
TNF-alpha inhibitors represent one of the most important areas of biopharmaceuticals by sales, with three blockbusters accounting for $8 \%$ of total pharmaceutical sale in Norway. With use of a unique natural policy experiment in Norway, this paper examines to what extent the identity of the third-party payer affects doctors' choice between the three available drugs. We are able to investigate to what extent the price responsiveness of prescription choices is affected when the identity of the third-party payer changes. The three dominating drugs in this market, Enbrel, Remicade, and Humira, are substitutes, but have had different and varying funding schemes - hospitals and the national insurance plan. We find that treatment choices are price responsive, and that the price response is considerably higher when the doctor's affiliated hospital covers the cost instead of a traditional fee-for-service insurance plan. When the doctors' hospitals are covering the cost of this treatment instead of insurance the total cost of treatment is significantly reduced.
\end{abstract}

JEL-Code: C35, D43, I18, L11.

Keywords: pharmaceuticals, discrete choice model, funding-schemes.

Dag Morten Dalen

BI Norwegian School of Management

dag.m.dalen@bi.no
Enrico Sorisio

PharmaNess / Italy

enrico.sorisio@pharmaness.it

\author{
Steinar Strøm \\ University of Oslo and the Frisch Centre \\ Oslo / Norway \\ steinar.strom@econ.uio.no
}

September 28, 2010

We are grateful for comments by seminar participants at HERO (University of Oslo), HEB (University of Bergen), the Norwegian Annual Health Economy Conference 2009, BI Norwegian School of Management, Abbott Norway, and the Norwegian Pharmacy Association. The research has benefitted from grants from the Norwegian Research Council. Farmastat kindly provided data for the study. 


\section{Introduction}

The agency problem faced by insurance companies and governments, and its consequences for health care financing has been subjected to extensive theoretical and empirical research. ${ }^{5}$ The moral hazard problem in health care arises due to third-party funding and doctors' superior information about diagnosis and preferred treatment choices. Pharmaceutical expenses - both on individual prescription drugs and on more specialized drugs used by hospitals - are often covered by medical insurance. Extensive insurance explains why pharmaceuticals markets often are characterized by price inelastic demand (see references below), and, subsequently, why many countries exert various means to control these expenses.

In an insurance-based health care system there are several candidates for being the third-party payer. When prescribing a drug on behalf of an insured patient, the cost may be covered by traditional insurance plans - private or public - on a fee-for-service basis or by the hospital with which the doctor and patient are affiliated. There are reasons to believe that the agency problem differs between a global hospital funding scheme and a fee-for-service approach adopted by traditional insurance plans. Treatment costs covered by the national insurance plan do not represent a direct cost for the doctor and the hospital. To the extent that treatment costs affect the choice of drug under a pure national insurance plan funding, this is explained by doctors' understanding and adherence to national guidelines for cost-effective treatment choices. When treatment costs are covered by the hospital, the opportunity costs becomes more "tangible" to the doctors. Increased treatment costs on one patient reduce available resources for other activities at the affiliated hospital. For this reason, treatment choices may be under a tighter control or monitoring when costs are covered by the local hospital instead of a national, and tax funded, insurance plan.

With use of a unique natural policy experiment in Norway, this paper examines to what extent the identity of the third-party payer affects doctors choice of treatment. More precisely, we are able to investigate to what extent the price responsiveness of prescription choices is affected when the identity of the third-party payer changes. Our case in point is the Norwegian market for Tumor Necrosis Factor (TNF) alpha inhibitors. To date TNF-alpha inhibitors represent the most important way to treat arthritis and other autoimmune diseases

\footnotetext{
${ }^{5}$ See McGuire (2000) for a review.
} 
(Feldmann and Maini, 2003). Treatment choices with TNF-alpha inhibitors in Norway are made by hospital doctors, and all patients receiving treatment are insured against the cost, but, importantly for our study, the funding source has differed, both between the three available drugs and over time.

When the market for TNF-inhibitors opened in Norway in 2000, the first entrant Enbrel was fully covered by the obligatory national insurance plan. The treatment with Enbrel is initiated by the hospital doctor, but the cost was automatically covered by the national insurance plan. The second entrant Remicade did not obtain the same type of coverage. Instead the treatment cost had to be fully covered by the doctor's affiliated hospital. Importantly, the hospitals' budget did not include earmarked grants for these patients. Cost of treatment with Remicade, therefore, competed with other expenses within the hospital. This sharp asymmetry in funding scheme reflects a quality attribute of the two drugs. Enbrel is administrated by the patients themselves (pump injections), while Remicade requires several hours infusion at hospitals. In fall 2002 the government modified the plan for Remicade by reducing the hospitals' share of treatment cost to $20 \%$. Choosing Remicade after fall 2002, the government required a copayment of $20 \%$ from the doctor's affiliated hospital. Enbrel maintained its full insurance plan coverage. The third entrant Humira is also administrated by pump injections by patients, and received the same funding plan as Enbrel when the drug entered in January 2003.

The important policy change exploited in our study, however, took place in 2006 . Then the asymmetry of financing between Enbrel and Humira, and Remicade was entirely removed by returning the entire funding responsibility to the hospitals for all three drugs. Since then all costs of treatment with TNF-alpha inhibitors have to be covered by the doctors' affiliated hospital. By creating large and exogenous variations in hospital and insurance plan treatment costs, these funding switches becomes the crucial source of identification in our empirical model.

We specify a simple discrete choice model in which the doctor's choice among the available of TNF-alpha inhibitors depends on the prices. Furthermore, the price response is allowed to vary with the identity of the third-party payer. Our main result shows that doctors' choice of TNF-alpha inhibitor is responsive to price differences, and that this price response becomes stronger when hospitals cover the costs. 
Running counterfactual experiments, we derive the economic magnitude of changes of the third-party payer. Remicade, which is the cheapest of the three drugs, gains 8 percentage point increase in market share by moving from insurance plan funding to hospital funding. This materializes as a 3-5 percent reduction in total treatment cost. Since these drugs are all on the top five sale value list in Norway ${ }^{6}$, the choice of the third-party payer has a non-trivial economic impact. Savings are shown to be far larger than the reduction in expected consumer surplus for these doctor-patient couples.

The reminder of the paper is organized as follows. In Section 2 we relate our paper to the existing literature. Section 3 briefly describes the market for TNF-alpha inhibitors. In Section 4 we describe the data used in the analysis. Section 5 presents the econometric model. The results are presented in Section 6, and we conclude in Sections 7.

\section{Related literature}

Our research relates to two strands of the health economics literature. One is the literature on pharmaceutical demand in general and in particular previous attempts to estimate price elasticities. The other is the literature studying the effect of reimbursement schemes on spending. Note, however, that these two areas of research are interlinked since many of the studies of price responses in pharmaceutical demand exploit variations in reimbursement schemes and patient charges.

Ellison et al. (1997) estimate a demand model for a class of antiinfective drugs called cephalosporins. Their data contains four different chemical substances, and three of these substances experienced significant generic entry in the sample period. The model, therefore, allows studying both therapeutic and generic substitution. Looking at substitution between different substances, they find evidence of low (and often insignificant) price responses in demand. One of the drugs comes out with a significant own-price elasticity of -0.3 . As expected, substitution between brand names and generics reveals much higher price responses. Besides being a different type of drug, treating patients with other types of diseases, cephalosporin drugs differ from our TNF-alpha inhibitors by having a relatively low level of hospital consumption.

\footnotetext{
${ }^{6}$ Norwegian Association of Pharmaceutical Manufacturers (2009)
} 
Another study related to ours is Berndt et al. (2003). They do not study the effect of insurance on prescription choices, but estimate a demand model for a growing market with competing brand names available. They use data for $\mathrm{H}_{2}$-antagonist antiulcer, and their data starts at the entry of the first patent Tagament. Similar to our study, therefore, they investigate the pharmaceutical demand in a market with several competing brand-name (patented) drugs. They develop a rich model that includes a dynamic component of diffusion. Their market share model allows the drug choice to depend on prices, in addition to marketing. Doctors' are found to respond to prices, but similar to the findings of Ellison et al. (1997), price responses appear to be relatively low. They find own-price elasticities in the range of about -0.3 and 0.6 .

Both Ellison et al. (1997) and Berndt et al. (2003) investigate the demand responses to changes in pharmaceutical prices. There is a larger literature studying the demand responses to changes in co-payment by patients. A seminal contribution was made by Leibowitz et al. (1985), who used data from the Rand Health Insurance experiment to study the relationship between the degree of cost sharing with patients and prescription drug utilization. They found that patients with a more generous insurance scheme buy more prescription drugs. Another early contribution, using monthly time-series from the National Health Service (NHS) in England, is O'Brien (1989). He found co-payment elasticities in the range of about -0.3 and 0.6. A more recent contribution along this line of research is made by Contoyannis et al. (2005). Using micro data (individual patients) from Quebec, they estimate the elasticity of expenditure for prescription drugs with respect to patients' marginal prices (cost sharing). These were found to be relatively low - in the interval -0.12 to -0.16 .

Iizuka (2007) is a recent contribution to the literature on agency problems in prescription drug market. In the Japanese market, doctors make profit from selling prescribed drugs. Using data with both prices and doctors' own mark-up, he estimates a nested logit demand model for the hypertension market, including 40 brands in 5 different therapeutic classes. Iizuka finds that prescription decisions are influenced by the size of mark-up, but that doctors care more about patient welfare than their own profit. Hence, if the retrial price of a brand increases, the doctor becomes less likely to prescribe that drug. Other papers studying the importance of doctor and prices in prescription choices are Coscelli (2000) and Lundin (2000). The main contribution of Lundin is to show how the level of patients' co-payment influences doctors choices 
(between generics and brand-name). He finds that doctors' are more responsive to patients' co-payment than the cost of the insurance provider.

Lundin (2000) relates to our analysis by showing that doctors' responses to prices are influenced by the funding source. In Lundin's analysis the two funding sources are the patients themselves or the insurance provider. In our paper, we are instead able to investigate different types of third-party funders - hospitals and national insurance plans. Hellerstein (1998) provides evidence of the importance of insurance plans for the agency problem in prescription choices. She finds that doctors with a higher fraction HMO-patients relative to patients who are enrolled in traditional insurance plans, more often prescribe generics instead of the brand-name drug. Since her data did not contain prices, however, she is not able to capture the effect on doctors' price responsiveness.

Our main contributions to this literature stems from the ability to investigate a multi-brand demand decision, with large and "exogenous" shifts in funding regimes. Exploiting this opportunity, we are able to provide new evidence on the importance of funding schemes for shaping doctors' prescription choices.

\section{The market for TNF-alpha inhibitors}

Biotechnology is considered to be one of the most important technologies that emerged in the last decades of the 20th century. The biotechnological revolution was expected to yield significant benefits to the pharmaceutical sector through improvements in drug discovery and development (Lawrence, 2006; Lawrence 2007; Walsh 2003). The biopharmaceutical market is now characterized by competition among few firms that act at a global level, and biotech drugs claim an increasing share of novel treatments approved by the regulatory authorities (Kneller, 2005). The number of biotech blockbusters, i.e. drugs on the market that have sales over 1 billion USD per year, is rapidly increasing. Recombinant therapeutic proteins represent the main business sector of biotechnological drugs, followed by monoclonal antibodies. Several proteins and antibodies are used in the treatment of arthritis and other autoimmune diseases, and the most important subgroup is described as tumor necrose factor (TNF) alfa inhibitors. 
There are three biotechnological drugs acting as TNF alpha inhibitor in the treatment of rheumatoid arthritis (RA). The first is Enbrel (etanercept), a recombinant protein of human origin: it was approved by the FDA in 1998 for the reduction of signs and symptoms of moderate to severe RA, and in Europe by EMEA in 1999; it is administered twice a week by subcutaneous injection. At the time of introduction, it was indicated for use by patients who had an inadequate response to one of the other disease-modifying anti-rheumatic drugs (DMARD) (Moreland et al., 1997), and in combination with Rheumatrex (methotrexate): clinical trials proved that the addition of etanercept to methotrexate therapy resulted in rapid and sustained improvement (Weinblatt et al., 1999). Enbrel gained approval also for the treatment of juvenile RA and psoriatic arthritis, and further studies demonstrated its effectiveness as compared with methotrexate in patients with early active RA (Bathon et al., 2000), making it a first-line treatment for RA and a leading brand within the new class of DMARDs. Enbrel was developed by Immunex, a biotechnology company that in 2001 was acquired by Amgen. The product is marketed jointly with Wyeth Takeda.

The second TNF-based RA product on the market is Remicade (infliximab), a chimeric (human and mouse) monoclonal antibody that proved to be safe and effective with persistently active RA not responding to methotrexate therapy (Lipsky et al., 2000). It is marketed by Centocor together with Schering Plough and the Japanese company Mitsubishi Tanabe Pharma. In Europe EMEA granted marketing authorization in March 2000. It is administered every four to eight weeks via an intravenous infusion that may take several hours to complete and requires qualified personnel monitoring of adverse reactions: this is considered as a disadvantage in comparison with Enbrel. Nevertheless, Remicade progressively increased its sales gaining high market shares. Price of Remicade is lower than Enbrel.

The third TNF alpha inhibitor in the market is Humira (adalimumab), a fully human monoclonal antibody approved by FDA in December 2002 and by EMEA in September 2003, and marketed by Abbott in the form of subcutaneous injection every two weeks, setting the drug price in parity with Enbrel. Its attracting dosing profile was considered a key success factor, but relatively short after its launch, the growth of sales slowed and it seemed not to threaten significantly the market position of its competitors. 
Since these drugs are expensive, and the leading products show also some important side effects, like tuberculosis (Antoni and Braun, 2002), other products than TNF-alpha inhibitors are used to treat the disease (like Rituxan, Orencia and Kineret). The profitability of the market stimulates new research - a number of pharmaceutical and biotechnological companies are currently trying to develop new products that may threaten the market leaders Enbrel and Remicade in the future (Sheridan, 2008).

Market penetration in terms of sales value has been highly successful in Norway. Sale of Enbrel, Remicade and Humira accounted for $8 \%$ of total pharmaceutical sale in Norway in $2008 .^{7}$

\section{Data}

The dataset consists of monthly wholesale sale value and quantity sold, expressed in defined daily doses (DDD), for each of the three drugs Enbrel, Remicade and Humira. The data set covers the months from January 2000 to March 2008, indicated as running from $t=1$ to $t=99$ in Figures 1 and 2 below. The price per DDD is constructed from combining the value and quantity information.

The following figure shows the monthly wholesale value of sale.

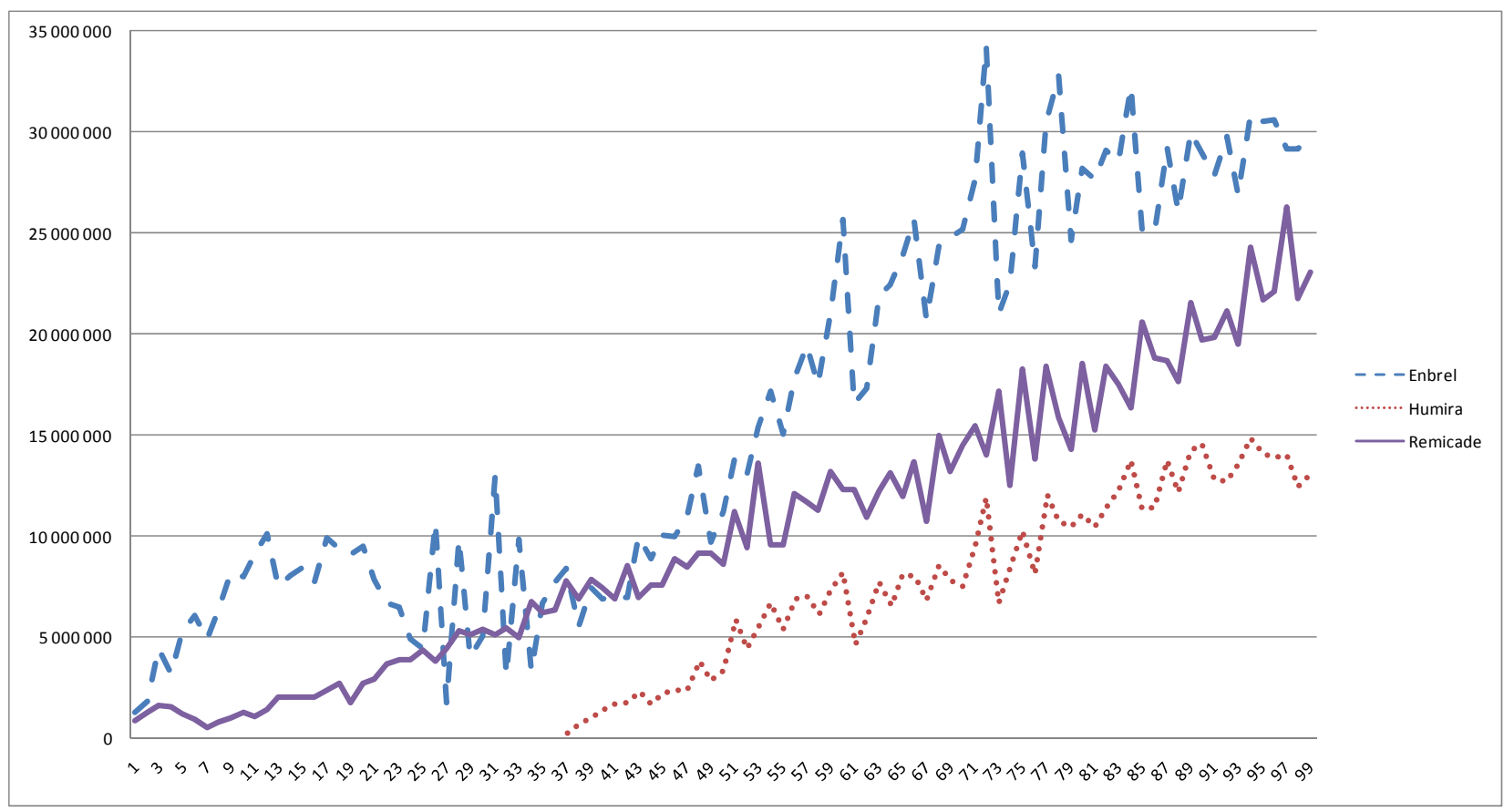

Figure 1: Monthly wholesale value of sale; 1000 NOK. As of September $20101 € \sim$ NOK 7.9

\footnotetext{
${ }^{7}$ Norwegian Association of Pharmaceutical Manufacturers. Facts and Figures (2009).
} 
The market opened early 2000, with the entry of both Enbrel and Remicade. Enbrel had a far stronger growth during the first year, and became soon the leading drug. In 2001-2002 Enbrel experienced problems of supplying the market. World wide capacity shortage forced the producer to reduce the sale of Enbrel in Norway. This explains the drastic reduction in sale value for Enbrel, and its volatility shown in Figure 1. In the fall 2003, the third drug, Humira, entered. Although Humira experienced a steady growth in the fast growing market, it never succeeded in capturing a larger market share.

The figure below shows the development of market shares.

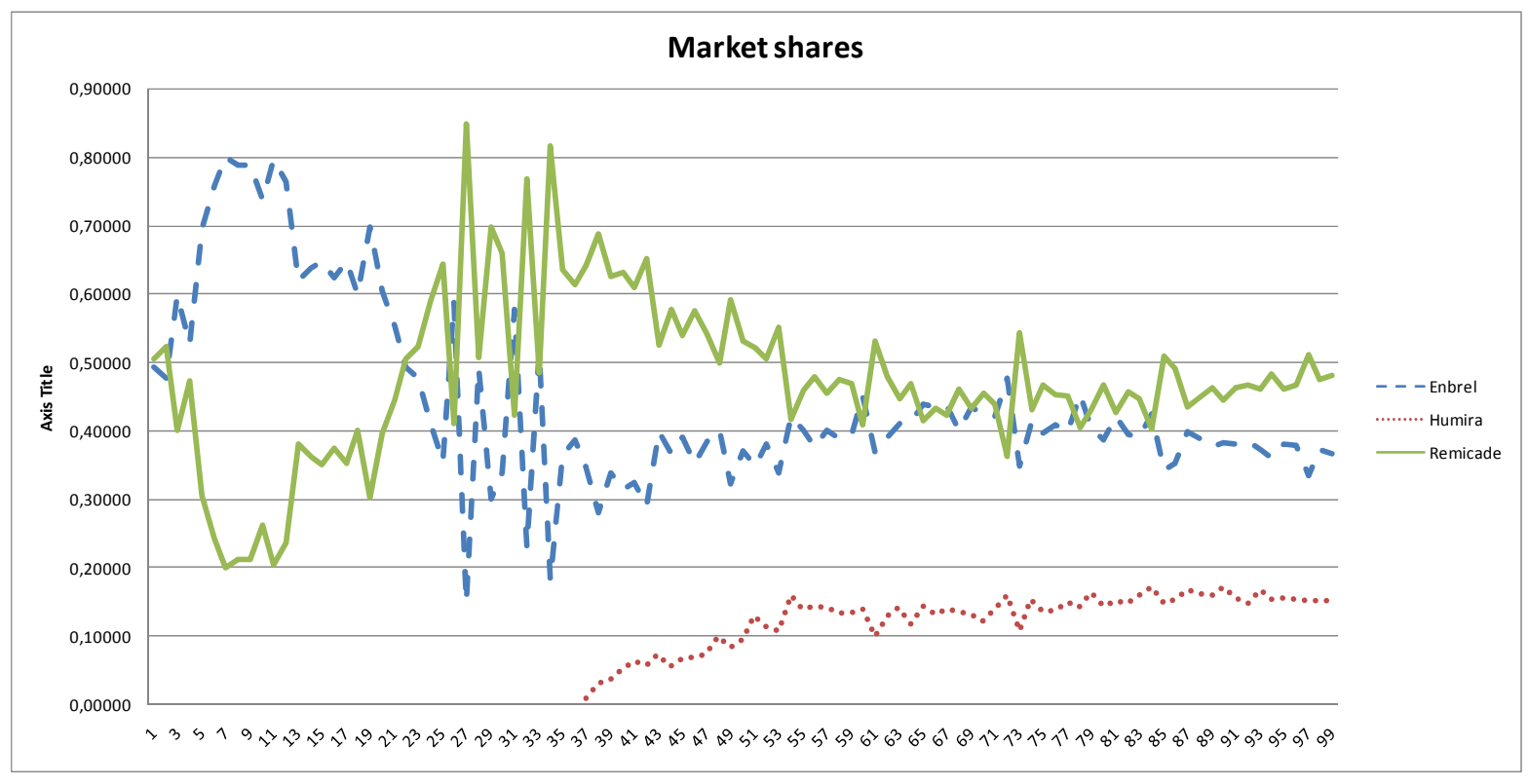

Figure 2: Market shares for the three drugs (DDD).

Within the first year, Enbrel reached a market share of 80 percent. The market share dropped rapidly, most triggered by the abovementioned shortage of production capacity. Since Remicade was the only alternative TNF-inhibitor in this period, it experiences an equivalent rise in its market share. Humira reached a market share close 9 percent after a few months.

The price of Enbrel has always been very high relative to Remicade. Except for the first couple of months, the wholesale price of Enbrel per DDD stayed between 350 and 400 NOK until late fall 2001. Then the price dropped to a level closer to 300 NOK per DDD. Remicade started out with a price of 200 per NOK, but came down to a level between 160 and 170 NOK per DDD after a few months. Humira entered with a price much above the price of Enbrel. 
Although Humira has kept its position as the price leader, the price gap (compared with Enbrel) has been narrowed during the sample period.

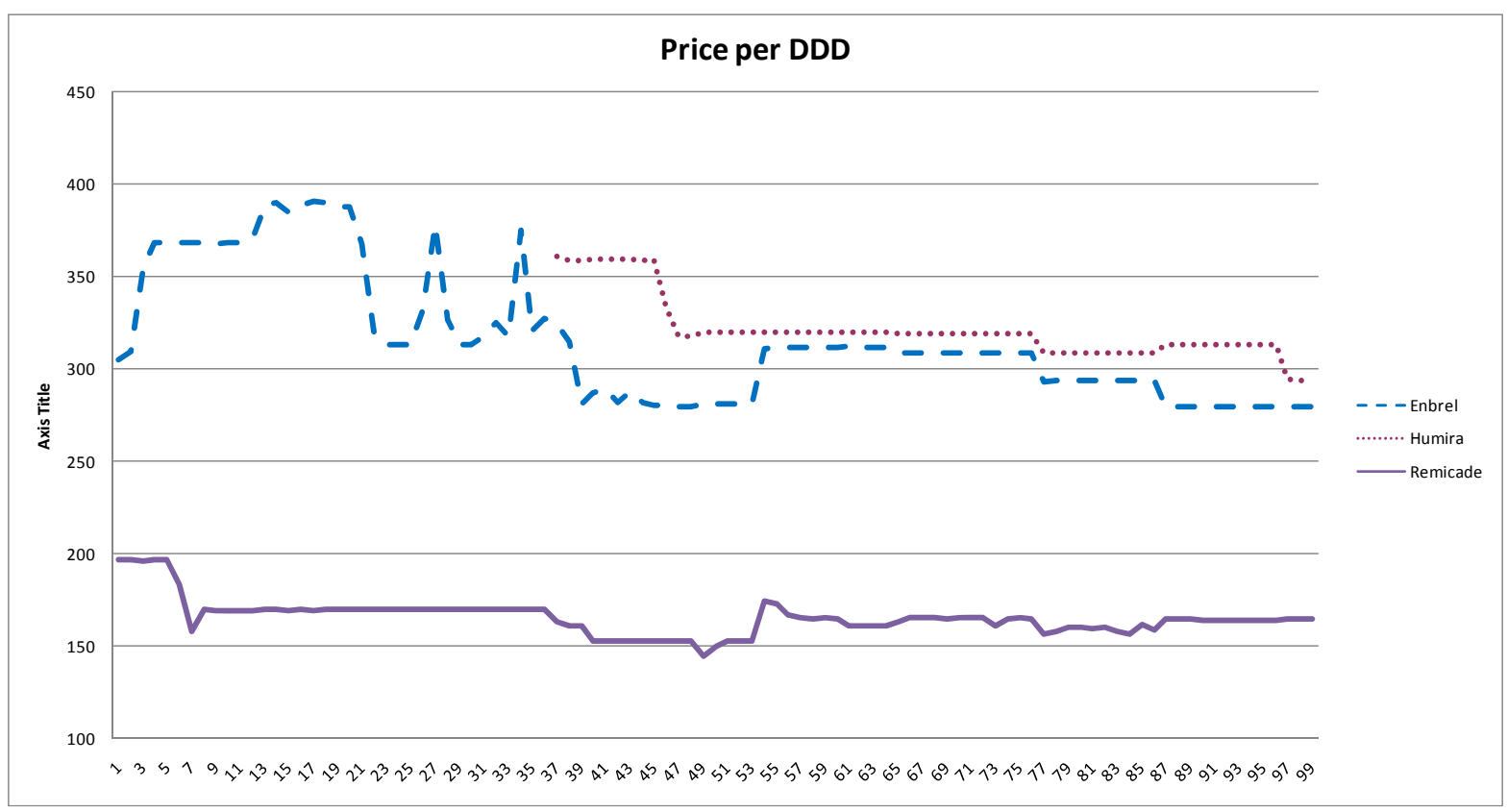

Figure 3. Wholesale price, NOK per DDD.

Note that pharmaceutical prices in Norway are regulated by a price cap. The cap is set to reflect the average of the three lowest prices on the similar drug in selected European countries, such as Sweden, Finland, Denmark, Germany, the UK, the Netherlands, Austria, Belgium and Ireland. The Regulation of 1999 mentioned that to some (minor) extent and in certain cases one should pay attention also to prices on related (but different substances) drugs sold in the Norwegian market and with the same treatment effect and to the cost of producing and distributing drugs. For practical purposes, however, the regulation implied that maximal prices on drugs in the Norwegian pharmaceutical market are set according to an international reference pricing system.

Summary statistics for the sample used in estimating our model is provided in Table 2. 
Table 2: Summary statistics

\begin{tabular}{|c|c|c|c|c|c|c|c|}
\hline Enbrel (obs: 99) & Mean & Median & Std. Dev. & Kurtosis & Asymmetry & Min & Max \\
\hline$D D D$ & 53249.77 & 46557.00 & 34755.95 & -1.40 & 0.34 & 4287.00 & 111829.00 \\
\hline Price & 315.39 & 308.30 & 34.98 & -0.33 & 0.93 & 279.37 & 390.66 \\
\hline Market share & 0.44 & 0.40 & 0.13 & 0.91 & 1.08 & 0.15 & 0.80 \\
\hline \multicolumn{8}{|l|}{ Humira (obs: 66) } \\
\hline$D D D$ & 25739.75 & 25076.00 & 14090.69 & -1.18 & -0.12 & 717.00 & 47531.00 \\
\hline Price & 321.20 & 319.00 & 16.90 & 1.31 & 1.38 & 293.55 & 360.60 \\
\hline Market share & 0.13 & 0.14 & 0.04 & 0.62 & -1.22 & 0.01 & 0.17 \\
\hline \multicolumn{8}{|c|}{ Remicade (obs: 99) } \\
\hline$D D D$ & 62542.05 & 58247.00 & 42225.41 & -1.00 & 0.31 & 3360.00 & 159655.00 \\
\hline Price & 165.41 & 164.78 & 9.56 & 3.72 & 1.40 & 144.63 & 196.55 \\
\hline Market share & 0.48 & 0.47 & 0.12 & 1.34 & 0.29 & 0.20 & 0.85 \\
\hline
\end{tabular}

We have chosen to restrict the sample period in our empirical analysis to $t=38-99$. The data reveals several reasons for this.

First, there are reasons to expect demand behavior - and in particular price responses - to be different in the early stage of a new pharmaceutical market compared with the more maturated market. In the early stage, doctors are unfamiliar with the particular technology of treatment (TNF-alpha inhibitors) - both its efficiency and its possible side-effects. In a more mature market, doctors have gained experience with the drug, and will be better able to make treatment choices for the individual patients. ${ }^{8}$ Gaining experience with TNF-inhibitors, the doctors will better able to take treatment costs into account when choosing between the available alternatives. Second, capacity shortage for the manufacture of Enbrel during the first years distorts demand. As seen from the data section, Enbrel experienced a sharp decline in sale 2001-2002 that was due to a global capacity problem of the manufacture. After a period of decline, sale and market shares were very unstable, until problems were resolved some months before the entry of Humira.

\footnotetext{
${ }^{8}$ See Berndt et al. (2003).
} 


\section{Econometric model}

The decision-making unit on the demand side is the physician, who acts as the patient's agent (Arrow, 1963). In making decisions, however, the physician needs to take into account the situation of each individual patient. In the formal model of demand, therefore, consumers are represented by physician-patient couples, $i=1, . . N_{t}$. The model is derived from a random utility model (see Train, 2002 for an overview of such models) in which consumers chooses among the available drugs, $j=1, \ldots, J$, to maximize utility. Utility is given by

$$
\text { (1) } \quad \mathrm{U}_{\mathrm{ijt}}=\mu_{\mathrm{jt}}-\mathrm{b}_{\mathrm{jt}} \mathrm{p}_{\mathrm{jt}}+\varepsilon_{\mathrm{ijt}}, \mathrm{i}=1,2,, \mathrm{~N}_{\mathrm{t}}, \mathrm{j}=1,2,3, \mathrm{t}=1,2,,, 61
$$

where $\mu_{j t}$ is an indicator of perceived treatment quality of $\operatorname{drug} j$ at time $t$. This is a common quality-indicator that applies to all patients that can benefit from TNF-alpha therapy. We will allow perceived quality to be time-dependent. $p_{j t}$ is the price variable associated with drug $j$, $\varepsilon_{\mathrm{ijt}}$ is a random variable distributed across individuals, alternatives and time. The coefficients $b_{\mathrm{jt}}$ are coefficients that capture the negative impact of the costs of treatment on utility. Note that $b_{\mathrm{jt}}$ are expected to be positive.

The costs of treatment with TNF-alpha inhibitors are covered by a third-party. There are two third-party payers. One is the National Insurance Plan (NIS) (termed "I"), and the other is the hospital with which the prescribing doctor is affiliated (termed " $\mathrm{H}$ "). As described in Section 1 , the funding split between the insurance plan and the hospital varies. At a given time $t$ the drug costs are fully paid by the hospital, fully covered by the insurance plan, or split between the two.

Let $p^{H}$ be the price covered by the hospital and $p^{I}$ the price covered by the national insurance plan.

$b_{H}$ and $b_{I}$ represent the doctor's responses to drug costs under the two different funding parties. The main objective of this paper is to investigate to what extent doctors' responses to drug costs is sensitive to the identity of the third-party payer - the social insurance plan or the hospital.

The particular funding plans used implies 


$$
\begin{aligned}
& p_{j t}^{H}=\alpha_{j t} p_{j t} \\
& p_{j t}^{I}=\left(1-\alpha_{j t}\right) p_{j t}
\end{aligned}
$$

The coefficients $b_{\mathrm{jt}}$ are then defined by

$$
b_{j t}=\alpha_{j t} b_{H}+\left(1-\alpha_{j t}\right) b_{I}
$$

When the market for TNF-apha inhibitors opened in 2000, Enbrel was fully covered by NIS (i.e. $\alpha_{1 \mathrm{t}}=0$ ), whereas Remicade was covered by the hospitals $\left(\alpha_{3 \mathrm{t}}=1\right)$. In the fall 2002 , the funding of Remicade changed. Hospital was to pay $20 \%$, whereas NIS paid the remaining $80 \%\left(\alpha_{3 \mathrm{t}}=0.2\right)$. When entering in 2003, Humira was given the same funding plan as Enbrel, i.e. fully coverage by NIS $\left(\alpha_{2 t}=0\right)$. In June 2006, the government then gave the full funding responsibility to the hospitals for all three drugs $\left(\alpha_{\mathrm{jt}}=1\right)$.

Since hospitals face budget constraints, the hospital's opportunity costs of drug treatment is strictly positive when $\alpha=1$. Reduced treatment costs will benefit other activities and patients at the same hospital. With coverage by the national insurance plan, the direct opportunity cost of the hospital will be zero. Choosing a drug that is fully paid by the insurance plan has no impact on the resources available for other activities at the hospital.

We have the following hypothesis:

$$
\begin{gathered}
\mathrm{H}_{0}: \quad b_{H}=b_{I} \\
\mathrm{H}_{1}: 0<b_{I}<b_{H}
\end{gathered}
$$

Doctors have guidelines that require cost consciousness in their choices of treatment. Therefore, we expect doctors to be price responsive also in the case of insurance plan coverage. However, in the case where the hospital pays the treatment costs, we expect doctors to become more concerned about these costs. This might be due to the personal incentives of doctors' to economize on costs in order to be able to spend extra resources on other patients, or just due to the fact that the hospital management has stronger incentives to monitor the individual doctor's treatment choices when these involves hospitals own budgets. 
By assuming $\varepsilon_{\mathrm{ijt}}$ to be independently, identically distributed extreme value (i.i.d. or type I extreme value) distributed across individuals and products, the probability that consumer $i$ will choose $\operatorname{drug} j$ at time $t$ is given by:

$$
\varphi_{\mathrm{jt}}=\operatorname{Pr}\left(\mathrm{U}_{\mathrm{ijt}}=\operatorname{Max}_{\mathrm{k}=1} \mathrm{U}_{\mathrm{ikt}}\right)=\frac{\mathrm{e}^{\mu_{\mathrm{jt}}-\mathrm{b}_{\mathrm{jt}} \mathrm{p}_{\mathrm{jt}}}}{\sum_{\mathrm{k}} \mathrm{e}^{\mu_{\mathrm{kt}}-\mathrm{b}_{\mathrm{jt}} \mathrm{p}_{\mathrm{jt}}}}
$$

We choose Enbrel to be the base product, here denoted product 1, and if we assume there is no outside good whose utility can be normalized to zero, these probabilities can be written ${ }^{9}$

$$
\varphi_{j t}=\frac{e^{\mu_{j t}-\mu_{1 t}-b_{j t} p_{j t}+b_{1 t} p_{1 t}}}{1+\sum_{k=2}^{3} e^{\mu_{k t}-\mu_{1 t}-b_{k t} p_{k t}+b_{1 t} p_{1 t}}}, j=2,3 ; t=1,2,, 61
$$

and

$$
\varphi_{1 \mathrm{t}}=\frac{1}{1+\sum_{\mathrm{k}=2}^{3} \mathrm{e}^{\mu_{\mathrm{kt}}-\mu_{1 \mathrm{t}}-\mathrm{b}_{\mathrm{kt}} \mathrm{p}_{\mathrm{kt}}+\mathrm{b}_{1 \mathrm{t}} \mathrm{p}_{1 \mathrm{t}}}}
$$

The observed parallel to the average of agents' probabilities that product $j$ is chosen, is the market share of the product, $m_{j}$. Because we only exploit aggregate data, our observed variable will be the market share, which gives us the following log-odd ratios:

$$
\ln \left(\frac{m_{j t}}{m_{1 t}}\right)=\mu_{j t}-\mu_{1 t}-b_{j t} p_{j t}+b_{1 t} p_{1 t}
$$

Doctors' perception of quality may change over time. There are several reasons for this. Manufactures may adopt different marketing strategies, both in terms of size and type, which change doctors' preferences over the three drugs over time. We do not have information about marketing resources in the Norwegian market, but if we assume that the market strategy is not changed frequently, a time trend will be able to capture changes in demand that are due to differences in the marketing strategy for the three drugs.

\footnotetext{
${ }^{9}$ Unfortunately, we are not able to construct an outside option to treatment with one of the three therapies. This would require a record of all patients with these diagnoses - including those without medical treatment. Our model, therefore, assumes that variations in prices covered by hospitals or the insurance schemes only affects the allocation of patients on different therapies (drugs), and not the total number of patients treated.
} 
Following the analysis of Berndt at al. (2003), we also allow quality perception to depend on accumulated sale. We expect doctors to be more willing to prescribe a certain drug the greater is the acceptance of that drug class in terms of the drug class' acceptance, measured with cumulative sale. This link between general acceptance and perceived quality might differ between the three drugs. We therefore consider the importance of local acceptance, by allowing perceived quality of drug $j$ depend on past sale of the same $\operatorname{drug} \mathrm{AX}_{\mathrm{j}} \cdot{ }^{10}$ These effects are introduced into the demand model by the following assumptions

$$
\mu_{\mathrm{jt}}=\tilde{\mu}_{\mathrm{jt}}+\tilde{\mathrm{c}}_{\mathrm{j}} \mathrm{t}+\mathrm{d} \cdot \mathrm{AX} X_{\mathrm{jt}-1}
$$

With this assumption, the demand equation to be estimated is

$$
\ln \left(\frac{m_{j t}}{m_{1 t}}\right)=a_{j t}-b_{j t} p_{j t}+b_{1 t} p_{1 t}+c_{j} t+d \cdot\left(A X_{j t-1}-A X_{1 t-1}\right)
$$

where $a_{j t}=\tilde{\mu}_{j t}-\tilde{\mu}_{1 t}, c_{j}=\tilde{c}_{j}-\tilde{c}_{1}$.

The parameter $a_{j t}$ is assumed to determined by two elements: $a_{j t}=a_{j}+\mu_{j t} . \mu_{j t}$ is a random i.i.d. term (white noise with zero expectation and constant variance, and with a possible covariance across the two equations), while $a_{j}$ is a deterministic drug-specific coefficient, that represents attributes and aspects that remain constant over time.

We have three funding plans: $\alpha=1, \alpha=0.2$, and $\alpha=0$ :

$$
b_{j t}=\left\{\begin{array}{c}
b_{H} \\
0.2 b_{H}+0.8 b_{I} \\
b_{I}
\end{array}\right.
$$

To capture these three regimes, we constructed two indicators:

\footnotetext{
${ }^{10}$ Recent contributions on the importance of doctors' learning and uncertainty for diffusion of new drugs are made by Crawford and Shum (2005) and Coscelli and Shum (2004) with use of individual doctor-patient data.
} 


$$
\begin{gathered}
A_{j t}^{I}=\left\{\begin{array}{l}
1 \text { if drug j at time } \mathrm{t} \text { has } \alpha=0 \\
0.8 \text { if drug j at time } \mathrm{t} \text { has } \alpha=0.2 \\
0 \text { if drug jat time } \mathrm{t} \text { has } \alpha=1
\end{array}\right. \\
A_{j t}^{H}=\left\{\begin{array}{c}
1 \text { if drug j at time } \mathrm{t} \text { has } \alpha=1 \\
0.2 \text { if drug j at time } \mathrm{t} \text { has } \alpha=0.2 \\
0 \text { if drug jat time } \mathrm{t} \text { has } \alpha=0
\end{array}\right.
\end{gathered}
$$

Using these variables, we reformulate the model to be estimated as

$$
\begin{aligned}
& \ln \left(\frac{\mathrm{m}_{2 \mathrm{t}}}{\mathrm{m}_{1 \mathrm{t}}}\right)=\mathrm{a}_{2}-\left[\mathrm{A}_{2 \mathrm{t}}^{\mathrm{I}} \mathrm{p}_{2 \mathrm{t}}-\mathrm{A}_{1 \mathrm{t}}^{\mathrm{I}} \mathrm{p}_{1 \mathrm{t}}\right] \mathrm{b}_{\mathrm{I}}+\left[\mathrm{A}_{1 \mathrm{t}}^{\mathrm{H}} \mathrm{p}_{1 \mathrm{t}}-\mathrm{A}_{2 \mathrm{t}}^{\mathrm{H}} \mathrm{p}_{2 \mathrm{t}}\right] \mathrm{b}_{\mathrm{H}}+\mathrm{c}_{3} \mathrm{t}+\mathrm{d} \cdot\left(\mathrm{AX}_{2 \mathrm{t}-1}-\mathrm{AX}_{1 \mathrm{t}-1}\right)+\mu_{2 t} \\
& \ln \left(\frac{\mathrm{m}_{3 \mathrm{t}}}{\mathrm{m}_{1 \mathrm{t}}}\right)=\mathrm{a}_{3}-\left[\mathrm{A}_{3 \mathrm{t}}^{\mathrm{I}} \mathrm{p}_{3 \mathrm{t}}-\mathrm{A}_{1 \mathrm{t}}^{\mathrm{I}} \mathrm{p}_{1 \mathrm{t}}\right] \mathrm{b}_{\mathrm{I}}+\left[\mathrm{A}_{1 \mathrm{t}}^{\mathrm{H}} \mathrm{p}_{1 \mathrm{t}}-\mathrm{A}_{3 \mathrm{t}}^{\mathrm{H}} \mathrm{p}_{3 \mathrm{t}}\right] \mathrm{b}_{\mathrm{H}}+\mathrm{c}_{3} \mathrm{t}+\mathrm{d} \cdot\left(\mathrm{AX}_{3 \mathrm{t}-1}-\mathrm{AX}_{1 \mathrm{t}-1}\right)+\mu_{3 \mathrm{t}}
\end{aligned}
$$

Note that the product of the indicators $\mathrm{A}^{\mathrm{I}}$ and $\mathrm{A}^{\mathrm{H}}$, and the prices $\mathrm{p}$, defines the prices faced by the insurance plan and the hospital, respectively. Crucial for identification of the price response coefficients is the exogenous variations in relative (i.e. between the three available drugs) insurance plan and hospital prices. We have no reason to believe that the extensive changes in the funding plan are correlated with changes in drug specific attributes. Note that the two equations in (12) have to be estimated using a simultaneous equations framework.

\section{Empirical results}

The model (12) was estimated with 3SLS, and the results are reported in Table 3 below. As explained in the data section, we have estimated the model on a restricted period $(\mathrm{t}=38-99)$. Model 1 includes the price variable and time trends, and in Model 2 cumulative sale is included among the regressors. 
Table 3: Results from the 3-stage least-square estimation, $t=38-99$ ( $t$-values in parentheses).

\begin{tabular}{lcc}
\hline & Model 1 & Model 2 \\
\hline & & \\
\hline Price - ins $b_{I}$ & 0.0026 & 0.0037 \\
& $(2.90)$ & $(3.84)$ \\
Price - hosp $b_{H}$ & 0.0045 & 0.0054 \\
& $(3.93)$ & $(4.70)$ \\
\hline Time trend- Humira & 0.0144 & 0.0164 \\
& $(11.30)$ & $(10.93)$ \\
Time trend- Remicade & -0.0110 & -0.0105 \\
& $(-4.77)$ & $(-4.56)$ \\
\hline Accum sale $(j)$ & & $3.54 \mathrm{e}-06$ \\
& & $(2.35)$ \\
$\mathrm{R}^{2}$ (Humira) & 0.7476 & 0.7700 \\
$\mathrm{R}^{2}$ (Remicade) & 0.2351 & 0.2357 \\
$\#$ observations & 61 & 61 \\
\hline
\end{tabular}

The price effects are highly significant and negative, implying that an increase in the price of a drug reduces the probability that doctors prescribe the drug. ${ }^{11}$ This is the case in both specifications. We also see that the estimated price response under hospital funding always exceeds the estimated price response under insurance plan funding. The results, therefore, support our main hypothesis that doctors become more price conscious when hospital covers the cost of treatment.

The time trend is significant and positive for Humira and significantly negative for Remicade (relative to Enbrel). This effect is also robust to model specification. As expected, past sale of a drug (Accum sale $(j)$ ) has positive effect on doctors' current willingness to prescribe that drug.

In order to better evaluate the economic magnitude of the price effect, we have calculated the elasticity of demand. The price response differs according to the funding source.

The own-price elasticity is given by

\footnotetext{
${ }^{11}$ Note that with our specification a positive price coefficient $b$ implies a negative price response on demand.
} 


$$
E_{j t}^{H}=\frac{\partial \hat{\varphi}_{j t}}{\partial p_{j t}} \frac{p_{j t}}{\hat{\varphi}_{j t}}=-\hat{b}_{j t} \cdot p_{j t} \cdot\left(1-\hat{\varphi}_{j t}\right)
$$

Using the results from Model 1 as the basis for calculation, we have

$$
E_{j t}^{H}=-\left(\alpha_{j t} 0.0026+\left(1-\alpha_{j t}\right) 0.0045\right) \cdot p_{j t} \cdot\left(1-\hat{\varphi}_{j t}\right)
$$

The figure below plots the point estimate of the elasticity with respect to the price covered by the hospital. The time is running from $t=38$ to $t=99$, which in the figures below is indicated by $\mathrm{t}$ running from $\mathrm{t}=1 \mathrm{to} \mathrm{t}=61$.

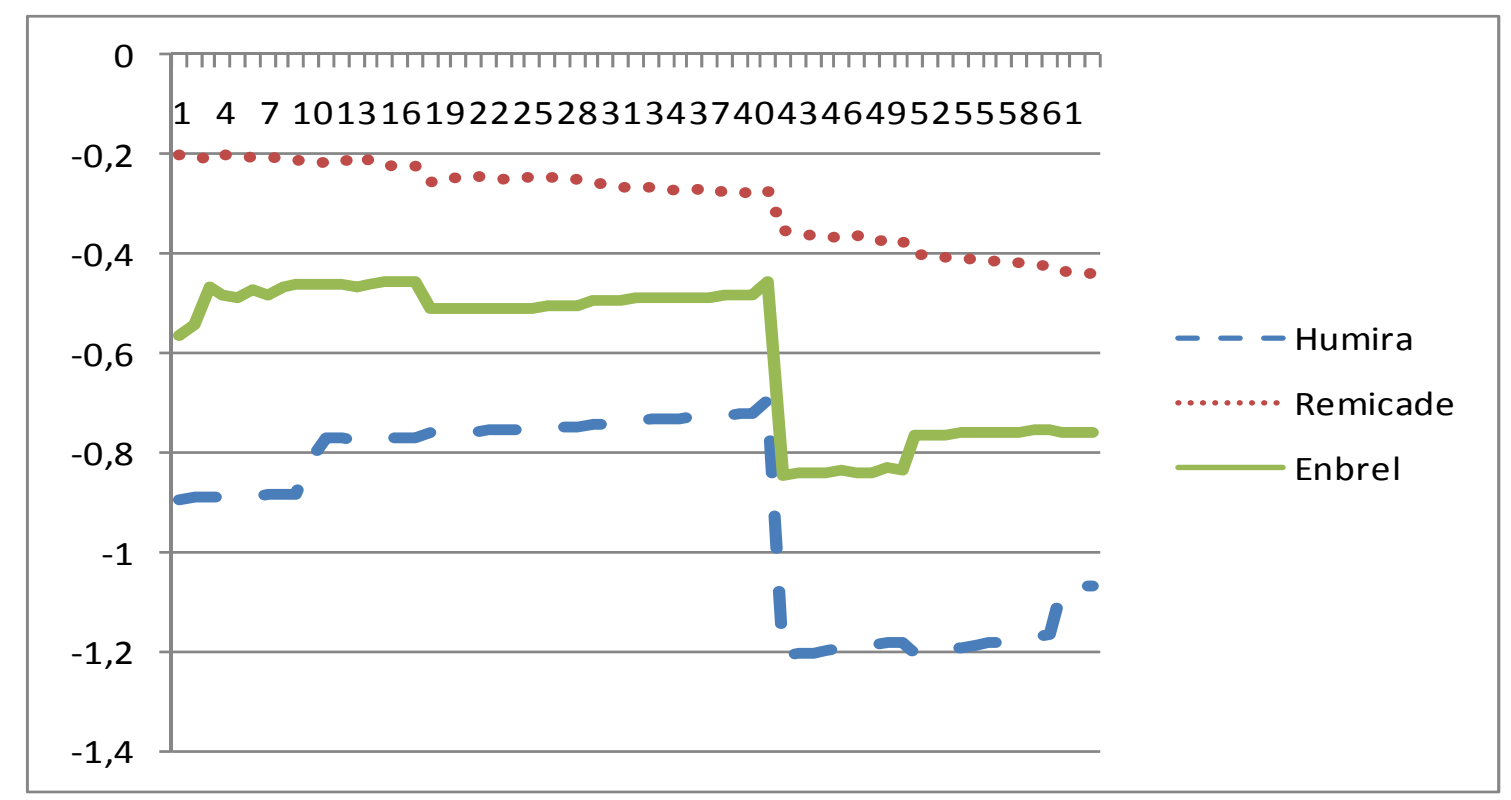

Figure 4: Price elasticity of demand (Model 1).

The sharp increase in the price response in June $2006(t=40)$ is due to the shift in funding source and is one of our main result. The shift in price coefficient when moving from pure social insurance funding to pure hospital funding has the effect of reducing the price elasticity for Humira from -0.69 to close to -1.2 . Remicade comes out with a less negative price elasticity. 
In order to gain insight into the economic importance of the funding plan, we have also calculated the expected market share and total treatment costs under different plans. ${ }^{12}$ Figure 5 shows the predicted market share for the three drugs, using the true funding plan for each drug in each month.

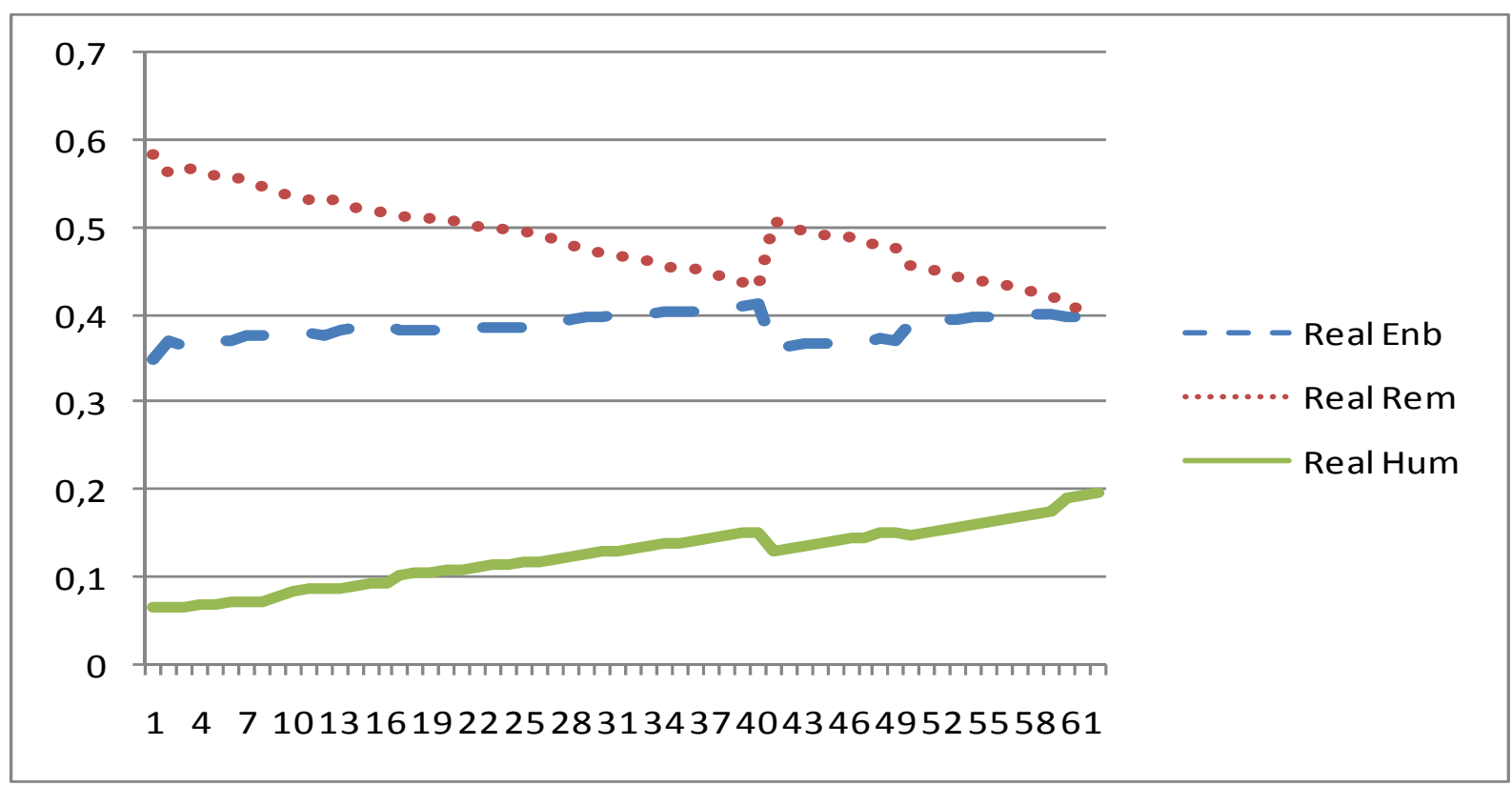

Figure 5: Predicted market shares under the different funding plan (Model 1).

According to the results of Model 1, Enbrel lost a market share of 5 percentage point when the funding of Enbrel and Humira shifted from the national insurance plan to the hospitals. Humira's loss of market share was smaller, 2-3 percentage point. Remicade which always has the lowest market price, gain market shares when doctors become more cost conscious. The predicted increase in market share due to the change in June 2006 amounts to 7-8 percentage point. $^{13}$

Using predicted market shares under the varying hospital funding and insurance plans, we have computed the difference in expected total treatment costs. These are reported in the Figure 6 below.

\footnotetext{
${ }^{12}$ The prices of these drugs are regulated by price caps set equal to the average of three lowest prices in a selection of other European countries. Since the Norwegian market represent only a small part of the European market, changes in funding plans here will not affect the prices.

${ }^{13}$ Since the model does not introduce an outside good, there is no effect on market size.
} 


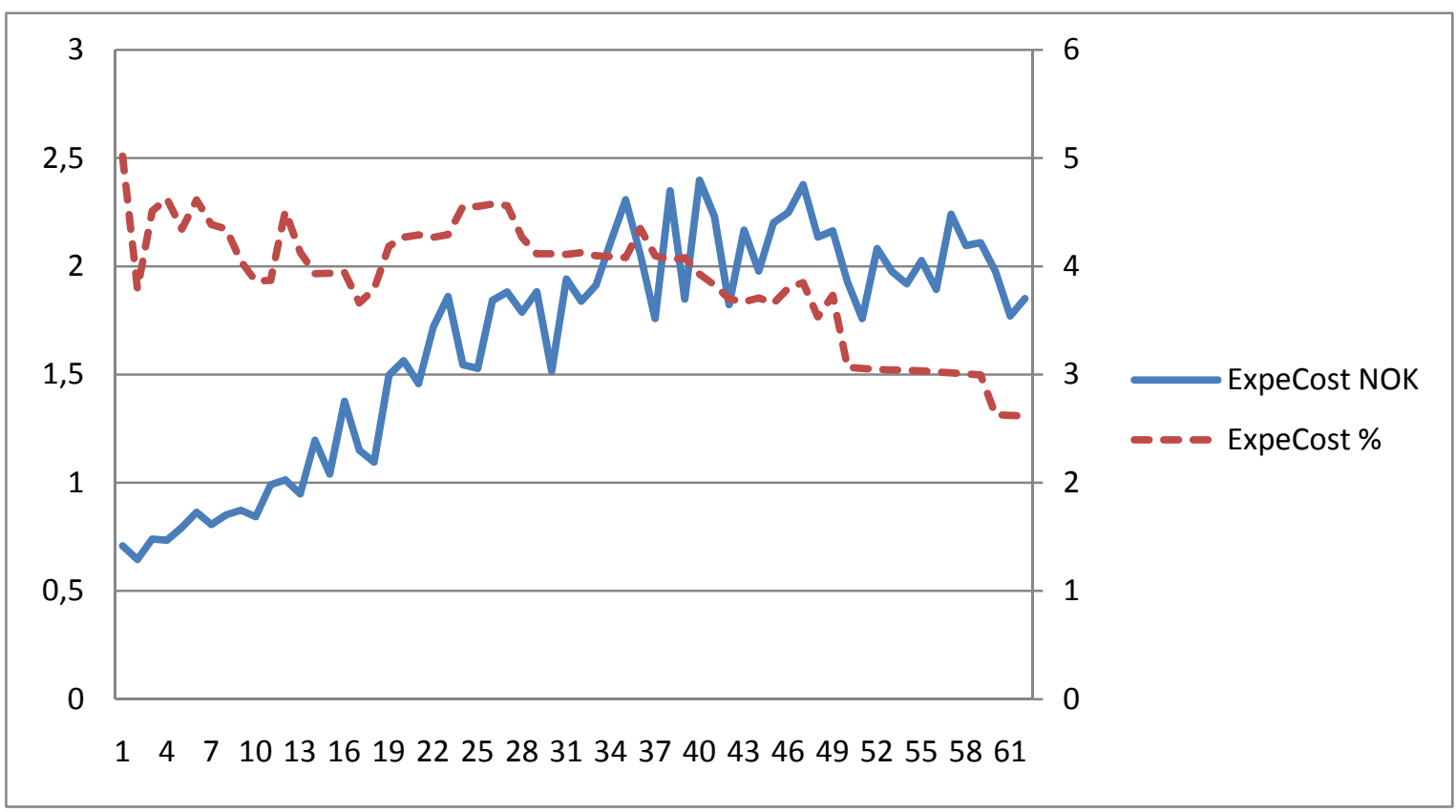

Figure 6: Predicted reduction in total treatment cost per month by moving from pure insurance plan funding to pure hospital funding. Mill. NOK (left axis) and percentage reduction (right axis).

Cost savings turn out be extensive. Monthly reduction in treatment costs amounts to up to 2.5 mill. NOK per month (the solid line - left axis). Relative to treatment costs, monthly savings amounts to between 5 to 3 percent (dotted line - right axis).

When doctors become more cost conscious, and change their prescription choices, the consumer surplus of the doctor/patient couples will - for given prices - fall. If utility is linear in income (so that price coefficient is constant with respect to income), then the expected consumer surplus becomes ${ }^{14}$

$$
\mathrm{E}\left(\mathrm{CS}_{\mathrm{t}}\right)=\sum_{\mathrm{j}=1}^{3} \frac{1}{\mathrm{~b}_{\mathrm{jt}}} \ln \left(\sum_{\mathrm{j}=1}^{3} \exp ^{\mathrm{V}_{\mathrm{jt}}}\right)+\mathrm{C}
$$

where $V_{j}$ is the deterministic part of the linear utility function in (1), $C$ is an unknown constant that represents the fact that the absolute level of utility cannot be measured. Using this expression we can compute the change in expected consumer surplus under different funding plans - insurance plan and pure hospital funding.

\footnotetext{
${ }^{14}$ See Williams (1977), Khajavi (1981), Small (1983) and Trajtenberg (1990) for demonstration and application of this.
} 
Since the unknown constant $\mathrm{C}$ enters expected consumer surplus both before and after the change, it drops out of the difference and can therefore be ignored when calculating changes in consumer surplus. In other to get total consumer surplus we need to determine the number of consumers each month. The exact number of patients is unknown, but following Sorisio and Strøm (2008) we have computed this to be the total number of defined daily doses used per month divided by 30 (the number days). Total surplus is then simply given by the number of consumers times the expected consumer surplus in (15). Using Model 1, the difference between total consumer surplus under national insurance plan and hospital funding is given Figure 7.

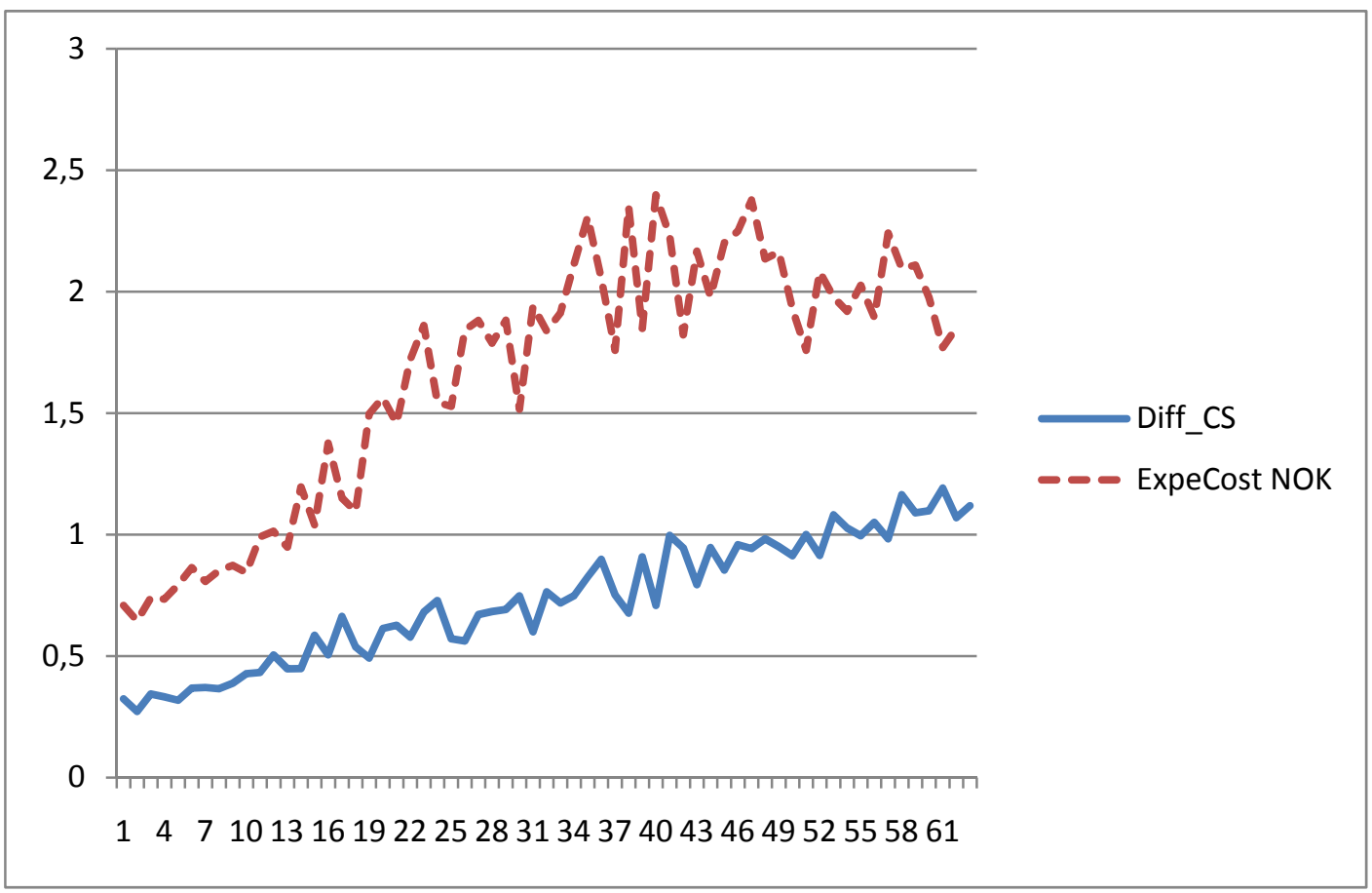

Figure 7: Difference in total consumer surplus under insurance plan and hospital funding (solid line), and reduction in total treatment cost (dotted line). Mill. NOK per month.

We thus see that the change in consumer surplus is economically important. Due to the steady increase in the number of patient, the difference is increasing over time, and reaches a level of 1-1.2 million NOK per month. However, comparing with monthly savings in treatment costs by moving from insurance plan funding to hospital funding, the net gain to the society is around 1 million NOK per month (reduction in treatment costs minus loss in consumer surplus). 


\section{Conclusion}

With use of a unique natural policy experiment in Norway, we have examined to what extent the price responsiveness of prescription choices is affected when the identity of the third-party payer changes. A discrete choice model is employed to capture the doctor's choice among TNF-alpha inhibitors. The price response is allowed to vary with the identity of the third-party payer. Our main result shows that doctors' choice of TNF-alpha inhibitor is responsive to price differences, and that this price response becomes stronger when hospitals cover the costs. The policy change is found to yield a 3-5 percent reduction in total treatment cost. Because these drugs are all on the top five sale value list in Norway ${ }^{15}$, the choice of the thirdparty payer has a non-trivial economic impact. Savings are shown to be far larger than the reduction in expected consumer surplus for the doctor-patient couples.

\footnotetext{
${ }^{15}$ Norwegian Association of Pharmaceutical Manufacturers (2009)
} 


\section{References}

Antoni C.and Braun J., (2002). "Side effects of anti-TNF therapy: Current knowledge", Clinical and Experimental Rheumatology, 20 (Suppl. 28), S152-S157.

Arrow, K.J., (1963). "The Welfare Economics of Medical Care," American Economic Review, 53, 941-973.

Bathon J.M., Martin, R.W., Fleischmann, R.M., Tesser, J.R., et al., (2000). "A comparison of etanercept and methotrexate in patients with early rheumatoid arthritis." New Engl. J. Med. 343 (22), 1586-1593.

Berndt E.R., R.S. Pindyck - P. Azoulay (2003). Consumption Externalities and Diffusion in PharmaceuticalMarkets: Antiulcer Drugs, Journal of Industrial Economics, 243-270.

Contoyannis, P., J. Hurley, P. Grootendorst, S-H. Jung, and R. Tamblyn (2005): "Estimating the price elasticity of expenditure for prescription drugs in the presence of non-linear price schedules", Health Economics, Vol. 14, pp. 909-923.

Coscelli,A. (2000), “The importance of Doctors' and Patients' Preferences in the Prescription Decision", Journal of Industrial Economics Vol. 3, pp. 349-369.

Coscelli,A and M. Shum (2004): "An empirical model of learning and patient spillovers in new drug entry", Journal of Econometrics, Vol. 122, pp. 213-246.

Crawford, G.S. and M. Shum (2005): "Uncertainty and Learning in Pharmaceutical Demand", Econometrica, Vol. 73, pp. 1137-1173.

Ellison, S.F., I. Cockburn, Z. Griliches, and J. Hausman (1997): "Characteristics of demand for pharmaceutical products: an examination of four cephalosporins", Rand Journal of Economics, Vol. 28, pp. 426-446.

Feldmann M., and Maini R.N. (2003). TNF defined as a therapeutic target for rheumatoid arthritis and other autoimmune diseases, Nature Medicine, 9(10), 2003, pp. 1245-1250.

Hellerstein J. (1998) "The importance of physician in the generic versus-trade name prescription decision”, RAND Journal of Economics, Vol. 29, pp. 109-136.

Iizuka, T. (2007). "Experts' Agency Problems: Evidence from the Prescription Drug Market in Japan,” RAND Journal of Economics, Vol. 38, pp. 844-862.

Khajavi, S. (1981): Optimal peak-load pricing, investment and service levels on urban streetsA numerical example, Trans. Research Record 807:7-14

Kneller R. (2005). The origins of new drugs, Nature Biotechnology 23:529 (2005). 
Leibowitz, A., W.G. Manning, J.P. Newhouse (1985): "The demand for prescription drugs as a function of cost-charing" Social Science and Medicine, Vol. 21, pp. 1063-1069.

Lundin, D. (2000): Moral hazard in physician prescription behaviour. Journal of Health Economics. Vol. 19.

Lawrence, S., (2006). Biotech drugs blaze a trail. Nat.Biotechnol. 24 (7), 736.

Lawrence, S., (2007). Pipelines turn to biotech. Nat.Biotechnol. 25 (12), 1342.

Lipsky P., van der Heijde, D., St Clair, E.W., Furst, D.E., et al., 2000. Infliximab and methotrexate in the treatment of rheumatoid arthritis. New Engl. J. Med. 343 (22), 1594-1602.

McGuire, T. G. (2000). "Physician Agency," in A.J. Cuyler and J.P. Newhouse, Handbook of Health Economics, North-Holland, 467-536.

Moreland, L.W., Baumgartner, S.W., Schiff, M.H., et al. (1997). Treatment of rheumatoid arthritis with a recombinant human tumor necrosis factor receptor (p75)-Fc fusion protein. $N$. Engl. J. Med. 337, 141-7.

Norwegian Association of Pharmaceutical Manufacturers, Facts and Figures (2009), http://www.legemiddelstatistikk.com/tf/2009/tall og fakta 2009.pdf.

O'Brien, B. (1989): “The effect of patient charges on the utilisation of prescription medicines", Journal of Health Economics, Vol. 8, pp.109-132.

Small, K.A. (1983). The incidence of congestion tolls on urban highways. J. Urban Econ. 13:90-111

Sheridan, C., (2008). Small molecule challenges dominance of TNF-alpha inhibitors. Nat.Biotechnol. 26 (2), 143-4.

Sorisio, E. and Strøm, S (2008). Innovation and the Nordic erythhropoeitin market, Rivista Internazionale di Scienze Sociali, No 1, 2008, 99-126

Train, K. E. Discrete Choice Methods with Simulation. Cambridge: Cambridge University Press, 2002.

Trajtenberg, M. Economic Analysis of Product Innovation. Harvard University Press, 1990.

Walsh, G., 2003. Biopharmaceutical benchmarks, Nat.Biotechnol. 21 (8), 865-870.

Weinblatt M.E., Kremer, J.M., Bankhurst, A.D., Bulpitt, K.J., et al., 1999. A trial of etanercept, a recombinant tumor necrosis factor receptor:Fc fusion protein, in patients with rheumatoid arthritis receiving methotrexate. New Engl. J. Med. 340 (4), 253-259. 
Williams, H.C.W. L. (1977). On the formation of travel demand models and economic evaluation measures of user benefit, Envir. And Planning, 9: 285-344. 


\section{CESifo Working Paper Series}

for full list see www.cesifo-group.org/wp

(address: Poschingerstr. 5, 81679 Munich, Germany, office@cesifo.de)

3164 Nikolaus Wolf, Europe's Great Depression - Coordination Failure after the First World War, September 2010

3165 Dan Kovenock and Brian Roberson, Conflicts with Multiple Battlefields, September 2010

3166 Jean-Pierre Ponssard and Catherine Thomas, Capacity Investment under Demand Uncertainty. An Empirical Study of the US Cement Industry, 1994-2006, September 2010

3167 Jørgen Juel Andersen, Jon H. Fiva and Gisle James Natvik, Voting when the Stakes are High, September 2010

3168 Michael Hoel, Is there a Green Paradox?, September 2010

3169 Scott Alan Carson, Nineteenth Century US African-American and White Female Statures: Insight from US Prison Records, September 2010

3170 Gil S. Epstein, Yosef Mealem and Shmuel Nitzan, Political Culture and Discrimination in Contests, September 2010

3171 Sara Fisher Ellison, Jeffrey Greenbaum and Wallace P. Mullin, Diversity, Social Goods Provision, and Performance in the Firm, September 2010

3172 Silvia Dominguez-Martinez, Randolph Sloof and Ferdinand von Siemens, Monitoring your Friends, not your Foes: Strategic Ignorance and the Delegation of Real Authority, September 2010

3173 Marcus Dittrich and Beate Schirwitz, Union Membership and Employment Dynamics: A Note, September 2010

3174 Francesco Daveri, Paolo Manasse and Danila Serra, The Twin Effects of Globalization - Evidence from a Sample of Indian Manufacturing Firms, September 2010

3175 Florian Blöchl, Fabian J. Theis, Fernando Vega-Redondo and Eric O’N. Fisher, Which Sectors of a Modern Economy are most Central?, September 2010

3176 Dag Morten Dalen, Marilena Locatelli and Steinar Strøm, Longitudinal Analysis of Generic Substitution, September 2010

3177 Armin Falk, Stephan Meier and Christian Zehnder, Did we Overestimate the Role of Social Preferences? The Case of Self-Selected Student Samples, September 2010

3178 Christian Fahrholz and Cezary Wójcik, The Bail-Out! Positive Political Economics of Greek-type Crises in the EMU, September 2010 
3179 Klaus Abberger and Wolfgang Nierhaus, The Ifo Business Cycle Clock: Circular Correlation with the Real GDP, September 2010

3180 Walter Krämer and Gerhard Arminger, “True Believers” or Numerical Terrorism at the Nuclear Power Plant, September 2010

3181 Bernard M.S. Van Praag, Dmitri Romanov and Ada Ferrer-i-Carbonell, Happiness and Financial Satisfaction in Israel. Effects of Religiosity, Ethnicity, and War, September 2010

3182 Dimitrios Koumparoulis and Paul De Grauwe, Public Capital, Employment and Productivity: An Empirical Investigation for Greece, September 2010

3183 John Whalley and Tanmaya Shekhar, The Rapidly Deepening India-China Economic Relationship, September 2010

3184 Andreas Schäfer and Thomas Steger, History, Expectations, and Public Policy: Economic Development in Eastern Germany, September 2010

3185 Thomas Eichner and Marco Runkel, Subsidizing Renewable Energy under Capital Mobility, September 2010

3186 Konstantinos Angelopoulos and James Malley, Fear of Model Misspecification and the Robustness Premium, September 2010

3187 Philip E. Graves, A Note on the Design of Experiments Involving Public Goods, September 2010

3188 Glenn Ellison, How does the Market Use Citation Data? The Hirsch Index in Economics, September 2010

3189 Barbara Hanel and Regina T. Riphahn, The Employment of Mothers - Recent Developments and their Determinants in East and West Germany, September 2010

3190 Alexander Haupt and Silke Uebelmesser, Integration, Mobility, and Human Capital Formation, September 2010

3191 Vincenzo Galasso and Paola Profeta, When the State Mirrors the Family: The Design of Pension Systems, September 2010

3192 Stéphane Zuber and Geir B. Asheim, Justifying Social Discounting: The RankDiscounted Utilitarian Approach, September 2010

3193 Alexander Kemnitz, Educational Federalism and the Quality Effects of Tuition Fees, September 2010

3194 Claudia M. Buch, Sandra Eickmeier and Esteban Prieto, Macroeconomic Factors and Micro-Level Bank Risk, September 2010

3195 May Elsayyad and Kai A. Konrad, Fighting Multiple Tax Havens, September 2010 
3196 Laszlo Goerke and Markus Pannenberg, Trade Union Membership and Dismissals, September 2010

3197 Ferdinand Mittermaier and Johannes Rincke, Do Countries Compensate Firms for International Wage Differentials?, September 2010

3198 John Boyd, Gianni De Nicoló and Abu M. Jalal, Bank Competition, Asset Allocations and Risk of Failure: An Empirical Investigation, September 2010

3199 Guido Heineck and Bernd Süssmuth, A Different Look at Lenin’s Legacy: Trust, Risk, Fairness and Cooperativeness in the two Germanies, September 2010

3200 Ingvild Almås, Tarjei Havnes and Magne Mogstad, Baby Booming Inequality? Demographic Change and Earnings Inequality in Norway, 1967-2000, October 2010

3201 Thomas Aronsson and Sören Blomquist, The Standard Deviation of Life-Length, Retirement Incentives, and Optimal Pension Design, October 2010

3202 Thorvaldur Gylfason and Eduard Hochreiter, Growing Together: Croatia and Latvia, October 2010

3203 Ken Burdett and Melvyn Coles, Tenure and Experience Effects on Wages: A Theory, October 2010

3204 Wendy Carlin, Good Institutions are not enough: Ongoing Challenges of East German Development, October 2010

3205 Tobias König and Andreas Wagener, Tax Structure and Government Expenditures under Tax Equity Norms, October 2010

3206 Daniel W. Sacks, Betsey Stevenson and Justin Wolfers, Subjective Well-Being, Income, Economic Development and Growth, October 2010

3207 Mario Larch and Wolfgang Lechthaler, Why "Buy American” is a Bad Idea but Politicians still Like it, October 2010

3208 Guglielmo Maria Caporale and Luis A. Gil-Alana, US Disposable Personal Income and Housing Price Index: A Fractional Integration Analysis, October 2010

3209 Bruno S. Frey, Withering Academia?, October 2010

3210 Eva Mörk, Anna Sjögren and Helena Svaleryd, Childcare Costs and the Demand for Children - Evidence from a Nationwide Reform, October 2010

3211 Dan Kovenock, Brian Roberson and Roman M. Sheremeta, The Attack and Defense of Weakest-Link Networks, October 2010

3212 Shmuel Nitzan and Kaoru Ueda, Prize Sharing in Collective Contests, October 2010 
3213 Erling Eide, Kristine von Simson and Steinar Strøm, Rank Dependent Utility, Tax Evasion and Labor Supply, October 2010

3214 Thomas Eichner and Marco Runkel, Interjurisdictional Spillovers, Decentralized Policymaking and the Elasticity of Capital Supply, October 2010

3215 Susan Athey and Glenn Ellison, Dynamics of Open Source Movements, October 2010

3216 Christian Bjørnskov, Axel Dreher, Justina A.V. Fischer and Jan Schnellenbach, Inequality and Happiness: When Perceived Social Mobility and Economic Reality do not Match, October 2010

3217 Thomas Cornelissen, Oliver Himmler and Tobias Koenig, Fairness Spillovers - The Case of Taxation, October 2010

3218 David E. Wildasin, State Corporation Income Taxation - An Economic Perspective on Nexus, October 2010

3219 Andreas Peichl, Nico Pestel and Hilmar Schneider, Does Size Matter? The Impact of Changes in Household Structure on Income Distribution in Germany, October 2010

3220 Alexander Kemnitz, A Simple Model of Health Insurance Competition, October 2010

3221 Johannes Becker and Marco Runkel, Even Small Trade Costs Restore Efficiency in Tax Competition, October 2010

3222 Paul Belleflamme and Martin Peitz, Digital Piracy: Theory, October 2010

3223 Andrea Kollmann and Friedrich Schneider, Why does Environmental Policy in Representative Democracies Tend to be Inadequate? A Preliminary Public Choice Analysis, October 2010

3224 Kai A. Konrad, Search Costs and Corporate Income Tax Competition, October 2010

3225 Spencer Bastani, Sören Blomquist and Luca Micheletto, The Welfare Gains of Age Related Optimal Income Taxation, October 2010

3226 Ben Lockwood, How should Financial Intermediation Services be Taxed?, October 2010

3227 Dag Morten Dalen, Enrico Sorisio and Steinar Strøm, Choosing among Competing Blockbusters: Does the Identity of the Third-Party Payer Matter for Prescribing Doctors?, October 2010 